\title{
Exogeneous energy supply and excitability of cells in embryonic atypical epidermis of Cynops cultured in vitro
}

\author{
Wu Weilin andChuang Hsiaohui \\ Shanghai Institute of Cell Biology, Academia Sinica
}

\begin{abstract}
Cells of in vitro cultured epidermis explants of ectoderm isolated at early gastrula stage, showed only weak excitability or even non-excitable at $6 \mathrm{~V}$ when examined electrophysiologically. If non-excitable explants were treated with 100 $\mathrm{m} M$ glucose, the action potential (AP) appeared and within $1 \mathrm{hr}$ reached its maximum. At the same time, their stimulus threshold became lowered gradually. And, if the glucose was washed out, AP gradually disappeared. If explants were treated with glucose of different concentrations, the percentage of explants which displayed AP increased with the increase of glucose concentration. When explants with approximately the same original stimulus threshold were treated with glucose of different concentrations, the stimulus threshold became lowered more in the more concentrated solution. If explants with different original stimulus thresholds were treated with glucose of the same concentration, the lowering of stimulus threshold was more obvious in those with higher original stimulus threshold. Other energy supplying substances used showed similar effect.
\end{abstract}

Key words: energy supply, embryonic epidermis cells, excitability.

\section{INTRODUCTION}

In the previous papers, it has been reported that cells in atypical epidermis, which developed from in vitro cultured ectoderm isolated at gastrula stage, in comparison with the epidermis in situ, possessed only very weak excitability when examined electrophysiologically[1-4]. If, however, such epidermis was cultured in combination with tissues from various germ layers[2, 4], or grafted to the posterior 
end of a normal embryo[3], the excitability could be raised to different degrees. In the later case, if grafted epidermis was amputated away from host embryo after it had displayed excitability, and cultured further, it became less excitable or even non-excitable like the control after a certain period of time[3].Since tissues of various kinds and their continuous contact or close association were necessary to maintain the excitability of cultured epidermis, it was supposed that the effective factor(s) might be non-specific and easily metabolized[3].

On the other hand, it was observed under EM that the mitochondria in cells of in vitro cultured epidermis showed frequent abnormalities (unpublished). It may be assumed that such abnormality might reflect functional deficiency of mitochondria which in turn interfered energy supply of the cell, causing the lowering of excitability or even becoming non-excitable at rather high stimulus strength. With this possibility in mind, experiments were carried out with various substances to study the effect of exogeneous energy supply on the excitability of in vitro cultured epidermis cells.

\section{MATERIAL AND METHODS}

Early gastrula of Cynops orientalis was used for isolation of ectoderm. The isolated ectoderm was cultured in Holtfreter solution. Both cultivation and electrophysiological tests were carried out under $20 \pm 1^{\circ} \mathrm{C}$.

Extracellular stimulation and intracellular recording technique was mainly used. A doublephasic insulated platinum wire $100 \mu \mathrm{m}$ in diameter connected with electronic stimulator SEN7103 (Nikon-kohden) was used for stimulation. For intracellular recording, a glass electrode filled with $3 \mathrm{M}$ KCL (resistance over $20 \mathrm{M}$ ) was used. Distance between stimulating and recording microelectrodes was less than $0.5 \mu \mathrm{m}$. Electric activity was recorded with microelectrode amplifier ME2-820 (Nikon-kohden) and was transferred into digitizing oscilloscope 5323 (Tektronix).

Before the treatment with various substances, explants were selected according to their response to electric stimuli. A maximum strength of $6 \mathrm{~V}$ with the time course fixed at $1 \mathrm{~ms}$ was applied. Explants which did not display action potential (AP) under such condition were considered to be non-excitable and will be used in most of the experiments, except for the experimental group 1c, explants which displayed AP below the threshold of $6 \mathrm{~V}$ were chosen.

Sometimes, intracellular stimulation and recording technique were also used. In such cases, the maximum current war $50 \mathrm{nA}$ and the time course fixed at $10 \mathrm{~ms}$.

Resting potentials (RP) of explants before and during the treatment were measured and recorded. Each explant was measured 5 times both before and during treatment in different cells with same microelectrode. The average value was taken as RPof that explant before and during treatment. By dividing the value of the later by the former, a ratio of RP for each explant was obtained, and the average value was used for comparison between experimental groups.

Following energy supply substances of analytical grade were used: glucose, galactose, su- 
crose, sodium pyruvate, sodium citrate, glycine and sodium ATP. All of them were dissolved in Holtfreter solution and adjusted $\mathrm{pH}$ to 7.5 .

\section{RESULTS}

\section{The effect of glucose on excitability of epidermis cells.}

\section{A. The effect of $100 \mathrm{mM}$ glucose}

In order to study the effect of glucose, $100 \mathrm{~m} M$ solution was first used to treat explants corresponding to stage 27 (the stage when auditory pits first appeared in embryo) which no AP displayed, when stimulus up to $6 \mathrm{~V}$ was applied. The excitability as well as RP were examined at certain intervals during and after the treatment. The results are summarized in figures 1 and 2 , from which it can be seen that, approximately $20 \mathrm{~min}$. after the beginning of treatment AP action began to appear and within an hour reached its maximum, and, if the glucose was washed

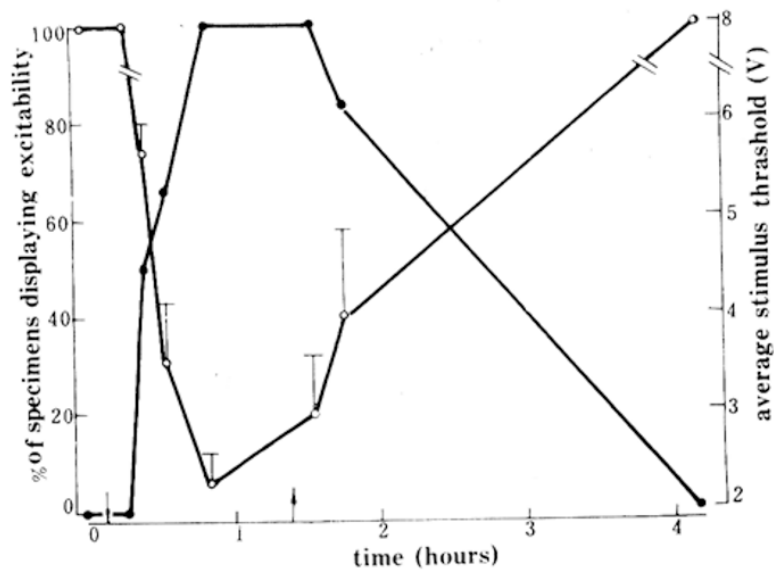

Fig. 1 Changes of percentage of excitable explants corresponding to stage 27 , and of average threshold during and after treatment with $100 \mathrm{mM}$ glucose.

$\downarrow$ Beginning of treatment,

$\downarrow$ End of treatment,

$\bullet-\bullet \%$ of excital le explants $(\mathrm{n}=6)$

$\circ-$ average stimulus threshold $(\mathrm{n}=3)$.

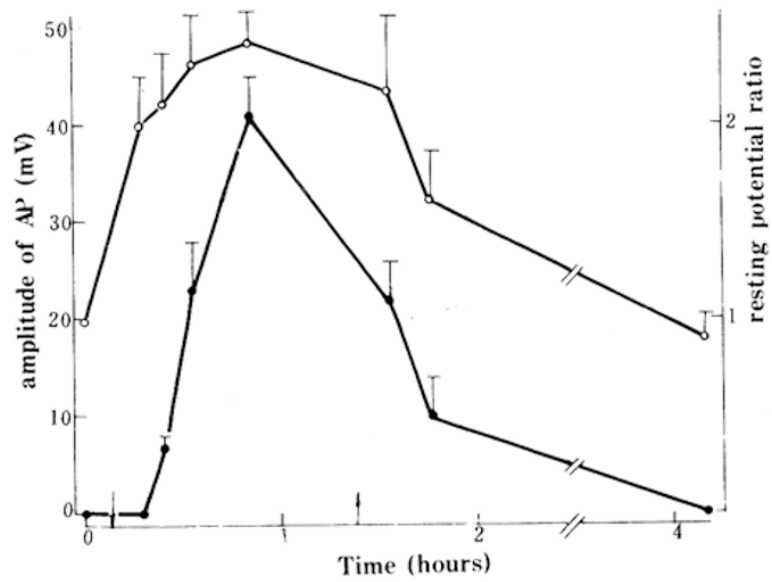

Fig. 2 Changes of amplitude of AP and of $R, P$ ratio of cultured epidermis corresponding to stage 27 during and after treatment with $100 \mathrm{mM}$ glucose.

$\downarrow$ Beginning of treatment,

$\downarrow$ End of treatment,

- - amplitude of $\mathrm{AP}(\mathrm{mV})(\mathrm{n}=4)$

○— - ratio of $\mathrm{RP}(\mathrm{n}=6)$ 
out, the AP gradually disappeared (see also Fig. 3). The ratio of RP changed in the same manner.

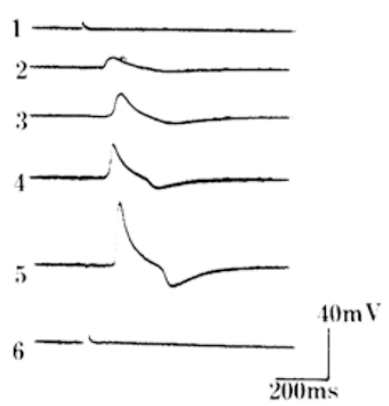

Fig. 3 The AP of cells in cultured epidermis corresponding to stage 27 during and after treatment with $100 \mathrm{~m} M$ glucose.

1)Before treatment, no AP dislayed:

2) 16 min. of treatment, AP appeared when stimulated with $6.0 \mathrm{~V}$;

3)and 4) 25 and 34 min. of treatment, amplitude of AP increased gradually:

5) 42 rain.of treatment,APwith highest amplitude, stimulus threshold $1.7 \mathrm{~V}$;

6) 2.5 hrs after the glucose was washed out, AP disappeared.

In addition, it should be mentioned that, when AP first appeared, not only the stimulus threshold remained comparatively high, the AP was only represented by a small elevation of low amplitude, and a certain length of time is required to attain the characteristic wave form. Besides, ceils of cultured explants were easy to become fatigue which means a rest period was needed after an excitation before they could be excited again. All of these phenomena resembled the first appearance of AP in epidermis cells in situ of stage 26 embryo[5].

\section{B. Glucose concentration and excitability of epidermis cells}

Explants corresponding to stages 27, 29 (when nasal pits appeared) and 31 (when lenses appeared) were treated respectively with $0.1,0.2,0.5,1.0,2.0,5.0,10,20$, 50 and $100 \mathrm{mM}$ glucose solutions, and the results are summarized in figures 4 and 5 .

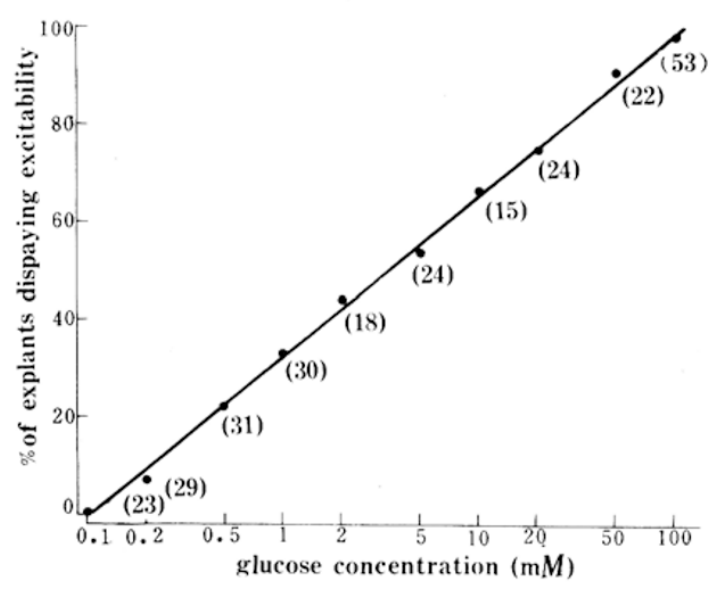

Fig. 4 Percentage of excitable explants in different glucose concentrations. Figures in brackets indicate number of explants. 


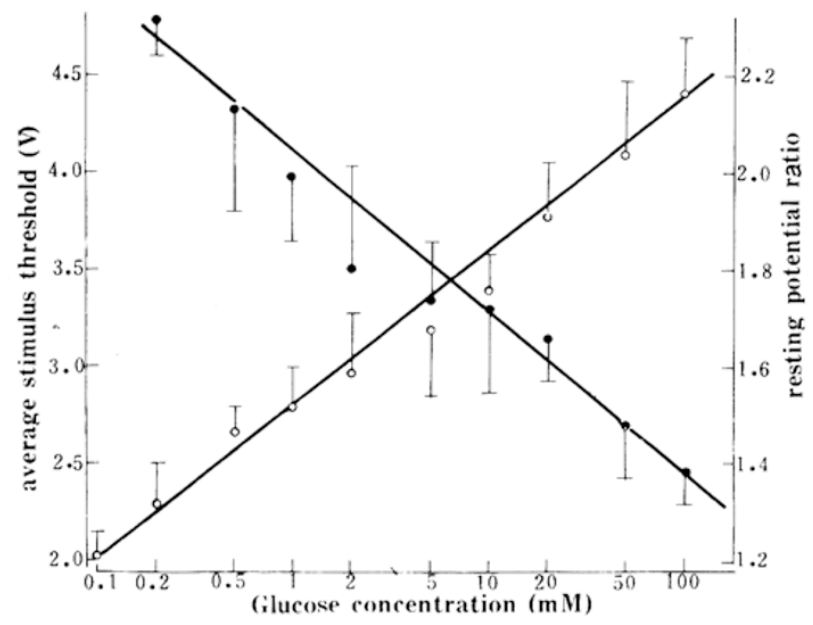

Fig. 5 Changes of stimulus threshold and of ratio of $R P$ of explants in different glucose concentrations.

$\bullet$ - stimlulus threshold (n 15--45) $\circ$ ratio of $\mathrm{RP}(\mathrm{n}=11--24)$

$0.1 \mathrm{~m} M$ glucose solution had no effect so that none of treated explants revealed excitability. But with the increase of concentration the percentage of excitable explants increased and reached to 98.1 in $100 \mathrm{~m} M$ group. The excitability of cells in culture is directly related with glucose concent-ration. Fig. 5 showed further that with the increase of glucose concentration, average stimulus threshold was lowered gradually, and the $R P$ ratio raised. Data presented in Figs. 4 and 5 indicate that the percentage of excitable explants and the $\mathrm{RP}$ ratio are proportional to Lg $\mathrm{N}$ of glucose concentration, and average stimulus threshold is inversely proportional to that.

\section{The effect of glucose on excitable explants}

It has been reported in previous papers[1,4] that one can find a few number of explants which do display AP without any treatment. Many such explants were selected to study their excitability change during glucose treatment. From results in Tabs. 1, 2, it is clear that: 1) if explants with approximately the same original

Tab. 1 Changes of stimulus threshold of explants corresponding to stage 27 and with approximately the same original threshold during treatment with different glucose concentrations.

\begin{tabular}{cccc}
\hline & No. of & \multicolumn{2}{c}{ average stimulus threshodl $(\mathrm{V})$} \\
\cline { 3 - 4 } $\begin{array}{c}\text { concentrations } \\
(\mathrm{mM})\end{array}$ & cases & original value & value during treatment \\
\hline 2 & 10 & $5.69 \pm 0.13$ & $4.34 \pm 0.32^{*}$ \\
10 & 8 & $5.70 \pm 0.14$ & $2.95 \pm 0.24^{* *}$ \\
\hline
\end{tabular}

* $\mathrm{P}<0.01, * * \mathrm{P}<0.001$ vs. before treatment. 
Exogeneous energy supply and excitability of embryonic epidermis cells

Tab. 2 Changes of stimulus threshold of explants corresponding to stage 27 with different original threshold during treatment with $10 \mathrm{mM}$ glucose

\begin{tabular}{ccc}
\hline No. of & \multicolumn{2}{c}{ average threshold $(\mathrm{V})$} \\
\cline { 2 - 3 } cases & original value & $\begin{array}{c}\text { value } \\
\text { during treatment }\end{array}$ \\
\hline 7 & $1.94 \pm 0.09$ & $1.60 \pm 0.07^{*}$ \\
3 & $4.13 \pm 0.33$ & $2.17 \pm 0.39 *$ \\
8 & $5.70 \pm 0.14$ & $2.95 \pm 0.24^{* *}$ \\
\hline
\end{tabular}

$* \mathrm{P}<0.05, \quad * * \mathrm{P}<0.001$ vs. before treatment

stimulus threshold were treated with glucose of different concentrations, the stimulus threshold became lowered to a greater degree in the more concentrated solution: 2) if explants with different original stimulus threshold were treated with glucose of the same concentration, the lowering of stimulus threshold was much more obvious in the explants with higher original threshold.

In an additional group the excitable explants were treated with $100 \mathrm{mM}$ glucose and the AP wave form during treatment was compared with those before treatment. As indicated in Fig. 6 and Tab. 3, it revealed an obvious increase in both the amplitude and duration. Thus glucose treatment renders cells with low excitability more excitable.

Tab. 3 Changes of AP amplitude and duration of excitable explants before and during treatment with $100 \mathrm{mM}$ glucose

\begin{tabular}{|c|c|c|c|c|c|c|}
\hline & \multirow[t]{2}{*}{ No. of cases } & \multicolumn{2}{|c|}{ before treatment } & \multicolumn{2}{|c|}{ during treament } & \multirow{2}{*}{$\begin{array}{l}\text { times } \\
\text { increased }\end{array}$} \\
\hline & & range & average & range & average & \\
\hline $\begin{array}{c}\text { Amplitude } \\
(\mathrm{mV})\end{array}$ & 9 & $16-56$ & $36 \pm 4$ & $37-61$ & $53 \pm 3 *$ & 1.5 \\
\hline $\begin{array}{c}\text { Duration } \\
(\mathrm{ms})\end{array}$ & 12 & $189-471$ & $279 \pm 22$ & $361-4667$ & $1362 \pm 388^{*}$ & 4.9 \\
\hline
\end{tabular}

* $\mathrm{P}<0.005$ vs before treatment.

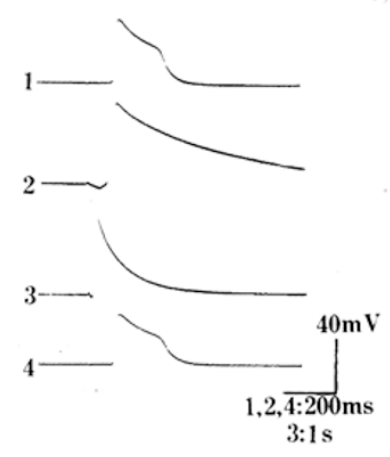

Fig. 6 Wave form changes of AP of excitable explants before, during and after treatment with $100 \mathrm{mM}$ glucose.

1. Before treatment, stimulus threshold 4.0V, duration $340 \mathrm{~ms} ; 2$ and $3.0 .5 \mathrm{hr}$. of treatment, threshold $2.3 \mathrm{~V}$, duration lengthened to $2.5 \mathrm{~S}: 4$. 50 rain. after treatment, threshold raised to $3.5 \mathrm{~V}$ and the duration shortened to that before treatment. 


\section{The effect of other energy supplying substances on the excitability of cultured epidermis cells.}

In this series, the effect of other energy supplying substances, as listed in Tab, 4. was examined within $1 \mathrm{hr}$. of treatment. From this table, it can be seen that: 1) similar to the treatment with glucose, all substances used showed obvious effect in raising the excitability of epidermis cells; 2) in all groups, the ratio of RP was increased, and 3) in different group, the excitability appeared at different time after the beginning of treatment. It can be assumed that the last mentioned phenomenon may be related with the utilization of substance concerned in metabolic pathway. For example ATP can be directly utilized and it acts most rapidly among all; galactose, sucrose and glycine have to be converted into other metabolites before entering into energy metabolism, and their effects appear later.

Tab. 4 The effect of various energy supply substances on the excitability of in vitro cultured embryonic epidermis cells

\begin{tabular}{lccccccc}
\hline & glucose & galactose & sucrose & glycine & $\begin{array}{c}\text { sodium } \\
\text { pyruvate }\end{array}$ & $\begin{array}{c}\text { sodiumn } \\
\text { citrate }\end{array}$ & ATP \\
\hline $\begin{array}{l}\text { No.of } \\
\text { cases }\end{array}$ & 53 & 12 & 14 & 12 & 12 & 12 & 19 \\
\hline $\begin{array}{l}\text { \% of } \\
\text { excitable } \\
\text { explants }\end{array}$ & 98.1 & 91.7 & 85.7 & 91.7 & 91.7 & 91.7 & 84.2 \\
\hline $\begin{array}{l}\text { Average } \\
\text { threshold } \\
\text { (V) }\end{array}$ & $2.47 \pm 0.16$ & $2.46 \pm 0.23$ & $3.08 \pm 0.44$ & $3.23 \pm 0.49$ & $2.68 \pm 0.38$ & $2.68 \pm 0.24$ & $3.33 \pm 0.16$ \\
\hline $\begin{array}{l}\text { Maximum } \\
\text { amplitude } \\
\text { of AP (mV) }\end{array}$ & 120 & 90 & 107 & 105 & 80 & 130 & 136 \\
\hline $\begin{array}{l}\text { Ratio of } \\
\text { resting } \\
\text { potential }\end{array}$ & $2.2 \pm 0.1$ & $1.8 \pm 0.1$ & $2.5 \pm 0.2$ & $1.7 \pm 0.1$ & $1.6 \pm 0.1$ & $2.5 \pm 0.2$ & $2.0 \pm 0.1$ \\
\hline $\begin{array}{l}\text { Time of } \\
\text { first appea- } \\
\text { rance of AP } \\
\text { (min.) }\end{array}$ & $19.7 \pm 1.4$ & $30.8 \pm 4.1$ & $25.9 \pm 3.926 .7 \pm 3.3$ & $16.0 \pm 1.8$ & $15.0 \pm 2.0$ & $10.7 \pm 1.6$ \\
\hline
\end{tabular}

Experiments to study the effect of different concentrations of ATP $(100 \mathrm{~m} M, 50$ $\mathrm{mM}$, and $10 \mathrm{mM}$ ) were also carried out. The percentages of excitable explants in each group were $84.2(\mathrm{n}=19), 66.7(\mathrm{n}=12)$ and $16.7(\mathrm{n}=6) \quad$ respectively,. The effect of ATP, like that of glucose, depended upon its concentration. 
Exogeneous energy supply and excitability of embryonic epidermis cells

\section{DISCUSSION}

In the present experiments, all the substances used are potent to influence the excitability of cultured embryonic epidermis cells. It seems that any substance which can be utilized by cells to produce ATP possesses such an effect. Experiments carried out with metabolic inhibitors provide support for this. Both inhibitors of aerobatic respiration $\left(\mathrm{NaN}_{3}\right.$ for example)as well as inhibitors of glucolysis ( $\mathrm{NaF}$, for example) influence the appearance of AP in excitable explants (unpublished). Besides, in treatments with different substances, there exists some correlations between the time of AP appearance and the conversion of substances used into ATP in metabolic pathway. Thus it may be supposed that energy supplying substances finally exerted their action through ATP they produced to effect the excitability of cultured epidermis cells.

In mammalian cells it has been shown that the AP wave form of anoxic ventricular cells resumed their noi'mal form when treated with glucose[6]; injection of ATP into heart muscle cells increased both their AP duration and amplitude[7]; and, abnormal AP of ventricular cells (treated with metabolic inhibitor) became normal upon injection of ATP[8,9].All these results which are in agreement with those obtained by us can be used to support our supposition.

It has been mentioned earlier that the excitability of cultured epidermis cells can be raised under the influence of various embryonic tissues either in Combination[1,4] or in grafting experiments[3]. However, when they lost their direct connection with the influencing tissues, they became gradually non-excitable again. To interpret such phenomenon with the present results, it is probable that all embryonic tissues influence the excitability through energy supply. And it may be concluded that it was insufficient energy supply which caused the early isolated and in vitro cultured embryonic epidermis cells less sensitive, or even non-excitable.

In our experiments, the effect of energy supplying substances on excitability may exert through the action on ionic pumps to increase RP. Treatment with glucose or ATP renders an obvious increment of $R P$ ratio and simultaneous raising of excitability. On the contrary, ratio of $\mathrm{RP}$ was reduced and the cells became less excitable or even non-sensitive when the explants Were treated with metabolic inhibitors (unpublished), and similar results were obtained with ouabain, the inhibitor of ATPase (unpublished). In the case of ventricular cells it is known that if the ATP supply is insufficient due to metabolic interference, the sodium pump can not operate normally and results in the lowering of RP.

There may be another possibility that substances used in our experiments act directly upon the ionic channels. That ATP level can directly regulates the activity of ionic channels has been shown with ventricular cells through the increase of $\mathrm{Ca}^{++}$current [8,9] and inhibition of $\mathrm{K}^{+}$current [13-17], which in turn raise the excitability and prolong the duration of AP. In our experiments, treatment with 
ATP brought about the prolongation of AP duration, including both the prolongation of plateau and slow down of repolarization process. This indicates that, as in muscle cells, ATP influences the activity of ionic channels $\left(\mathrm{K}^{+}\right.$and/or $\mathrm{Ca}^{++}$ channel) of epidermis cells.

Besides, it has been shown with neurons of Helix and Aplysia that, as one of the source material for protein phosphorylation, ATP may participate in phosphorylation process of channel protein[18-22]. Whether the same possibility exists in the amphibian embryonic cells remains to be examined.

Our experiments indicate further that the dependence of energy supply of embryonic epidermis cells and adult ventricular cells seems to be different. Though the excitability of muscle clls were lowered due to insufficient ATP supply, as revealed by the shortening of both the duration and amplitude, yet the excitability did not disappear under the stimulus applied. In epidermis cells, however, stimulus threshold raised but also the excitability vanished completely in case of insufficient energy supply, and if the exogeneous energy supplying substances were washed out, the explants became non-excitable like those before treatment. Thus amphibian embryonic epidermis cells seem to be more sensitive to the insufficiency of energy supply than adult mammalian cells.

\section{REFERENCES}

[1] Wu WL, Chert YH, ChuangHH. On the excitability of the epidermis and the atypical epidermis of Cynops orientalis embryos. Acta Biol Exp Sinica 1987; 20: 77-87.

[2] Chuang HH, Wu WL, Sun YA. The role of mesoderm in the epithelial conductivity in urodelian embryos .Acta Biol Exp Sinica 1983; 16: 235-239.

[3] Chuang HH, WU WL, Sun YA. ON the conductivity of the atypical embryonic epithelium of urodeles. Acta Biol Exp Sinica 1982; 15: 255-263.

[4] Wu WI, Chuang HH. Experiments influencing the excitability of the in vitro cultured urodelian embryonic epidermis ceils. Acta Biol Exp Sinica 1989; 22:

[5] Chunag HH, Wu WI, Sun YA. The appearance and disappearnce of epithelial conductivity in Cynops orientalis embryos. Acta Biol Exp Sinica 1982; 15:439-501.

[6] McDonald TF, Macleod DP. Metabolism and the electrical activity of anoxic ventricular muscle. J Physiol 1973; 229: 559-582.

[7] McDonald TF, Macleod DP. The effect of 2,4-dinitrophenol on the electrical and mechanical activity metabolism and ion movements in guinea-pig ventricular muscle. $\mathrm{Br} \mathrm{J}$ Pharmal 1972; 44: 711-722.

[8] Taniguchi J, Noma A, Irisawa H. Modification of the cardiac action potential by intracellular injection of adenosine triphosphate and related substances in guinea-pig single ventricular cells. Circ Res 1983; 53: 131-139.

[9] Irisawa H, Kokubun S. Modulation by intracellular ATP and cyclic AMP of the slow inward current in isolated single ventricular cell of the guinea-pig. J Physiol 1983; 338:312-337 
[10] Thomas RC. Electrogenic sodium pump in nerve and muscle cells. Physiol Rev 1972; 52: 563-594.

[11] Demello WC. Metabolism and electrical activity of the heart: action of 2,4-dinitrophenol and ATP. Am J Physiol 1959; 196: 377-380.

[12] Payet MD, Schanne OF, Ruiz-leretti E, Demers JM. Slow inward and outward currents of rat ventricular fibers under anoxia. J Physiol (Paris) 1978; 74: 31-35.

[13] Noma A. ATP-regulated $\mathrm{K}^{+}$channels in cardiac muscle. Nature 1983; 305: 147-148.

[14] Trube G, Hescheler J. Inward-rectifying channels in isolated patches of the heart cell membrane: ATP-dependence and comparison with cell-attached patches. Pflugers'Arch 1984; 401 : 178-184.

[15] Noma A, Shibasaki T. Membrane current through adenosine-triphosphate-regulated potassium channels in guinea-pig ventricular cells. J Physiol 1985; 262: 463-480.

[16] Kakei M, Noma A, Shibasaki T. Properties of adenosine-triphosphate-regulated potassium channels in guinea-pig ventricular cells. J Physiol 1985; 363: 441-462.

[17] Spruce AE, Standen NB, Stanfield PR. Studies of the unitary properties of adenosine5-triphophate-regulated potassium channels of frog skeletal muscle. J Physiol 1987:382: 213-236.

[18] Kaczmarek LK, Strong JA, Kauer JA. The role of protein kinases in the control of prolonged changes in neuronal excitability. Prog in Brain Res 1986; 69: 77-90.

[19] Lemos JR, Novak-Hofer I, Levitan IB, Regulation of ion channel activity by protein phosphorylation. Prog in Brain Res 1986; 69: 107-118.

[20] Shuster M J, Camardo S, Siegelbaum SA, Kandel ER. Modulation of the "S" $\mathrm{K}^{+}$channel by cAMP-dependent protein phosphorylation in cell-free membrane patches. Prog in Brain Res 1986; 69: 119-132.

[21] Sperlakis N. Regulation of calcium slow channels and potassium channels of cardiac muscle by cyclic nucleotides and matabolism. In: Dhalla GN, Beamish RE, eds. "' Heart Function and Metabolism". 1986; 25-65.

[22] Kostyuk PG, Kononenko NI, Shcherbatko AD. cAMP-activated ionic channels in the nerve cell membrane. In: Ovchinnikov YA, Hucho F. eds. " receptors and Ion Channels" 1987 ; $141-148$.

Received 22-12- 1988.

Accepted 16-1-1989. 